İşletme Akademisi Dergisi
2020, $1(3): 206-216$
DOI:10.26677/TR 1010.2020 .542
Dergi web sayfasi: www.sakder.org

Araștırma Makalesi

\title{
Denetçi Cinsiyetinin Denetim Görüşü Üzerindeki Etkisi: BIST 100 Endeksinde Bir Araştırma
}

\section{Doç. Dr. Ahmet TANÇ}

Nevşehir Hacı Bektaş Veli Üniversitesi, İktisadi ve İdari Bilimler Fakültesi, İşletme Bölümü, Nevşehir. atanc@nevsehir.edu.tr, www.orcid.org/0000-0002-4119-8207

\section{Öğr. Gör. Dilek ÇARDAK}

Nevşehir Hacı Bektaş Veli Üniversitesi, Gülşehir Meslek Yüksekokulu, Lojistik Programı, Nevşehir. dilekcardak@nevsehir.edu.tr, www.orcid.org/0000-0001-8561-9467

\section{Öz}

Bağımsız denetim faaliyetleri uzun yıllardan beri gerçekleştirilmesine rağmen, 2001 yılında Amerika'da yaşanan finansal skandallar üzerine, tüm dünyada finansal raporlama sistemleri ve bağımsız denetim firmaları sorgulanmaya başlanmıştır. Yaşanan bu olaylar üzerine bağımsız denetim faaliyetlerinin önemi giderek artmış ve bağımsız denetim bileşenleri üzerine çok sayıda çalışma yapılmıştır.

$\mathrm{Bu}$ çalışmanın amacı bağımsız denetçi cinsiyetinin, denetim görüşü üzerinde etkisi olup olmadığını tespit etmeye çalışmaktır. Çalışmada bağımsız denetçi cinsiyetinin, denetim görüşü üzerinde etkisini belirleyebilmek için Kamuyu Aydınlatma Platformunda (KAP) bulunan BIST 100 Endeksinde yer alan işletmelerin 2019 yılına ait denetim raporlarından elde edilen veriler kullanılmıştır. KAP sistemi ve ilgili işletmelerin web sayfaları üzerinden elde edilen veriler KiKare Bağımsızlık testi kullanılarak analiz edilmiştir.

Nihai olarak çalışmanın kısıtlarından bahsedilmiş ve gelecekte bu konuda çalışma yapacaklara önerilerde bulunulmuştur.

Anahtar Kelimeler: Bağımsız Denetim, Bağımsız Denetçi Cinsiyeti, Denetim Görüşü

Makale Gönderme Tarihi: 30.08 .2020

Makale Kabul Tarihi: 15.09 .2020

\section{Önerilen Atıf:}

Tanç, A., Çardak, D. (2020). Denetçi Cinsiyetinin Denetim Görüşü Üzerindeki Etkisi: BIST 100 Endeksinde Bir Araştırma, İşletme Akademisi Dergisi, 1(3): 206-216.

(C) 2020 İşletme Akademisi Dergisi. 


Journal of Business Academy
2020,1 (3): $206-216$
DOI: $10.26677 / \mathrm{TR} 1010.2020 .542$
Web pages: www.isakder.org

Research Article

\title{
The Effect of Auditor Gender on Audit Opinion: A Research in the Bist 100 Index
}

\author{
Assoc. Prof. Ahmet TANÇ \\ Nevşehir Hacı Bektaş Veli University, Faculty of Economics and Administrative Sciences, \\ Department of Business, Nevşehir \\ atanc@nevsehir.edu.tr, www.orcid.org/0000-0002-4119-8207
}

\section{Lecturer Dilek ÇARDAK}

Nevşehir Hacı Bektaş Veli University, Gülşehir Vocational School, Logistics Program, Nevşehir dilekcardak@nevsehir.edu.tr, www.orcid.org/0000-0001-8561-9467

\begin{abstract}
Although independent auditing activities have been carried out for many years, financial reporting systems and independent audit firms have started to be questioned all over the world in 2001 regarding financial scandals in America. The importance of independent audit activities on these events has gradually increased and many studies have been carried out on independent audit components.

The purpose of this study is to try to determine whether the gender of the independent auditor has an impact on the audit opinion. In the study, the data obtained from the 2018 audit reports of the companies included in the BIST 100 Index in the Public Disclosure Platform (PDP) were used to determine the effect of the independent auditor gender on the audit opinion. The data obtained from the PDP system and the web pages of the related enterprises were analyzed using the ChiSquare Independence test.

Finally, the limitations of the study were mentioned and suggestions were made to those who will work on this issue in the future.
\end{abstract}

Keywords: Independent Audit, Independent Auditor Gender, Audit Opinion

Received: 30.08 .2020

Accepted: 15.09 .2020

\section{Suggested Citation:}

Tanç, A., Çardak, D. (2020). The Effect of Auditor Gender on Audit Opinion: A Research in the Bist 100 Index, Journal of Business Academy, 1(3): 206-216.

(C) 2020 Journal of Business Academy. 


\section{GİRIŞ̧}

Küresel ekonominin giderek büyümesiyle birlikte ticari hayatta, karar alabilmek için bilgilerin güvenilirliği çok önemli bir husus haline gelmektedir. Bilgilerin güvenilirliği bilgiyi kullananlar ve bilgiyi sunanlar arasındaki çıkarlarda, bir farklılık olduğunda daha fazla önemli hale gelmektedir. 2000'li yıllarda Amerika'nın en büyük enerji şirketi Enron'un iflas etmesi, diğer yaşanan muhasebe skandalları ve denetim başarısızlıkları gibi olaylar temel amacı çıkar grupları arasındaki güvenceyi sağlamak olan bağımsız denetime güvenin azalmasına neden olmuştur. Amerika Birleşik Devletleri ve diğer bazı ülkelerde ortaya çıkan finansal raporlama skandalları sonucunda finansal tabloların güvenilirliği sorgulanmaya başlamıştır.

Sunulan bilgilere olan güven duyma ihtiyacı ile birlikte bağımsız denetimin önemi ve bağımsız denetim gereksinimi her geçen gün artmaktadır. Bu doğrultuda denetim, iktisadi faaliyet ve olaylarla ilgili iddiaların önceden belirlenmiş kriterlere uygunluğunu araştırmak ve sonuçları ilgililere aktarmak amacıyla tarafsızca kanıt toplayan ve bu kanıtları değerleyen sistematik bir süreçtir (Selimoğlu, Özbirecikli ve Uzay, 2017). Bağımsız denetim kavramı, “Bağımsız denetçinin mali tabloların bütün yönleri ile yürüklükteki finansal raporlama standartları çerçevesinde hazırlandığı ve önemli nitelikteki yanlışlıkların bulunmadığı hususunda yüksek derecede güvence içeren görüş beyan etmesi" olarak tanımlanmaktadır (Selimoğlu ve Yeşilçelebi, 2014).

Türkiye'de 660 Sayılı Kanun Hükmünde Kararname ile 2 Kasım 2011'de Kamu Gözetimi Muhasebe ve Denetim Standartları Kurumu (KGK)'nun kurulması ve 1 Temmuz 2012 tarihinde yürürlüğe giren 6102 Sayılı Türk Ticaret Kanunu (TTK) ile bağımsız denetim kavramı daha önemli hale gelmiştir.

KGK Bağımsız Denetim Yönetmeliği'nin 1. Bölümünün 4. Maddesine göre bağımsız denetim, "Finansal tablo ve diğer finansal bilgilerin, finansal raporlama standartlarına uygunluğu ve doğruluğu hususunda, makul güvence sağlayacak yeterli ve uygun bağımsız denetim kanıtlarının elde edilmesi amacıyla denetim standartlarında öngörülen gerekli bağımsız denetim tekniklerinin uygulanarak defter, kayıt ve belgeler üzerinden denetlenmesi ve değerlendirilerek rapora bağlanması" olarak ifade edilmektedir (Bağımsız Denetim Yönetmeliği, 2015).

Bağımsız denetim firmaları tarafından gerçekleştirilen denetim faaliyetlerinde, kamuya açıklanacak ya da Sermaye Piyasası Kurulu'na (SPK) gönderilecek mali tabloların Uluslararası Muhasebe İlke ve Standartlarına uygun bir şekilde hazırlanıp hazırlanmadığı kontrol edilmektedir. Bir başka ifadeyle mali tablolarda sunulan bilgilerin doğru, dürüst ve gerçeğe uygun olup olmadığı incelenmektedir. Diğer yandan bağımsız denetimin geçerliliğinden bahsedebilmek için de denetim ilke ve kurallarına uyulması zorunludur (Erdoğan, 2002).

KGK Bağımsız Denetim Yönetmeliği'nde 1. Bölümün 4. Maddesine göre bağımsız denetçilerin, “01/06/1989 tarihli ve 3568 sayılı Serbest Muhasebeci Mali Müşavirlik ve Yeminli Mali Müşavirlik Kanununa göre yeminli mali müşavirlik ya da serbest muhasebeci mali müşavirlik ruhsatını almış meslek mensupları arasından kurum tarafından yetkilendirilen kişilerden" olabileceği belirtilmiştir (Bağımsız Denetim Yönetmeliği, 2015). Bağımsız denetçi, denetim çalışmaları sonucu incelediği müşteri işletme finansal tablolarına ilişkin denetim görüşünü, Denetim Standartlarına göre denetçi raporunda açıklamalıdır. Denetçi "olumlu görüş", "olumsuz görüş", "şartlı görüş" ve "görüş bildirmekten kaçınma" şeklindeki dört görüş türünden en uygun olanını seçer. Denetçi nihai olarak denetim raporunda denetim görüşünü bildirerek denetim faaliyetini sonlandırır (Selimoğlu, Özbirecikli ve Uzay, 2017).

Bağımsız denetim raporu, denetimin yapıldığı zamanda, işletmenin mali tablolarının gerçekleri yansıttığını, işletmenin bilançosunda yer alan tüm aktif ve pasif hesapların kanuni defter ve belgelere, Türkiye Muhasebe Standartlarına ve Uluslararası Muhasebe Standartlarına uygun 
olup olmadığını gösterir (Erdoğan, 2002). Bağımsız denetim raporunun kalitesine etki eden bir takım niteliksel özellikler bulunmaktadır. Bu niteliksel özelliklerden bir tanesi de denetim faaliyetini gerçekleştiren denetçinin cinsiyetidir.

$\mathrm{Bu}$ çalışmanın amacı bağımsız denetçi cinsiyetinin, denetim görüşü üzerinde etkisi olup olmadığını tespit etmeye çalışmaktır. Bu amaç doğrultusunda gerekli analizlerin yapılabilmesi için BIST 100 endeksindeki işletmelerin bağımsız denetim raporlarından denetçi cinsiyeti bilgisine ulaşılmıştır. Veriler incelendiğinde 100 işletmedeki denetçi cinsiyet dağılımının; 19'nun kadın, 81'inin ise erkek şeklinde olduğu görülmektedir.

Selimoğlu vd. (2020), muhasebe mesleğine yönelik üst kuruluşlar ve meslek odalarında kadın yöneticilerin ve kadın yönetim kurulu üyelerinin erkeklere göre çok az sayıda olmasının nedenini araştırmak için gerçekleştirdikleri çalışmalarında, yönetimde kadın sayısının az olmasının nedeni olarak, kadın muhasebecilerin üstlendikleri ev sorumlulukları ve annelik rolleri olduğunu tespit etmişlerdir.

Gerçekleştirilen çalışmalar ve istatistiki veriler, cinsiyete dayalı mesleki ayrımcılık konusunda kadınların daha dezavantajlı durumda olduğunu göstermektedir. Çalışma yaşamında kadınlar, toplumsal cinsiyet ya da ayrımcılık gibi birtakım engellerle karşılaşmaktadırlar (Parlaktuna, 2010). Dünya çapında üst yönetimdeki kadın çalışanların oranı son 16 yılda giderek yükselmiştir. Ancak bu yükselişe rağmen çalışma yaşamında kadın çalışanların erkek çalışanlara oranı hala düşük seviyelerdedir. 2019 yılındaki oranlara bakıldığında dünya çapında üst yönetimdeki kadın çalışanların oranı \%29 iken erkek çalışanların oranının \%71 olduğu görülmektedir (Lagerberg ve Schmidt, 2020).

Son yıllarda bağımsız denetim faaliyetlerinin öneminin giderek artması ve kadının çalışma yaşamındaki varlığının önem kazanması gibi gelişmeler yaşanmaktadır. Yaşanan bu gelişmeler doğrultusunda çalışmanın konusu bağımsız denetçi cinsiyeti ve denetim görüşü çerçevesinde oluşturulmuştur. Bağımsız denetçi cinsiyetinin denetim görüşü üzerindeki etkisini tespit etmek amacıyla çalışmada, literatür incelenmiş ve denetçi cinsiyeti üzerine gerçekleştirilen çalışmalar aktarılmıştır. Daha sonra çalışmanın analizinde kullanılacak yöntem ve örneklem açıklanarak, yapılan analiz sonucunda elde edilen bulgulara yer verilmiş ve tartışma-sonuç bölümüyle çalışma sonlandırılmıştır.

\section{LITERATÜR TARAMASI}

Amerika'dan çok daha önce Kuzey Avrupa ülkelerinden olan Finlandiya, Danimarka ve İsveç'te 2005 'ten beri, denetim raporunda sorumlu denetçinin sslak imzasının bulunması yasal bir zorunluluktur. Bu doğrultuda sorumlu denetçiye ilişkin cinsiyet, mesleki tecrübe gibi özellikler ile ilgili akademik çalışmalar yapılmıştır (Ittonen ve Peni, 2012).

Türkiye'de 12.06.2006 tarih ve 26196 sayılı Resmi Gazete'de yayımlanan "Sermaye Piyasasında Bağımsız Denetim Standartları Hakkında Tebliğ "de bağımsız denetim raporlarında denetçinin adının bulunması bağımsız denetim kuruluşu unvanına ek olarak sorumlu denetçi adı, soyadı ve imzasının bulunması zorunluluğu vardır (Sermaye Piyasasında Bağımsız Denetim Standartları Hakkında Tebliğ, 2006). Daha sonra KGK'nın kurulması ile birlikte SPK mevzuatında da yeni düzenlemelerle uyumlaştırılmaya gidilmiştir. 18.03.2014 tarih ve 28945 sayılı Resmî Gazete'de KGK tarafından yayınlanan Bağımsız Denetim Standardı (BDS) 700’ e göre bağımsız denetim raporunda bağımsız denetçinin adının bulunması zorunlu hale getirilmiştir (Finansal Tablolara İlişkin Görüş Oluşturma ve Raporlama (BDS 700) Hakkında Tebliğ, 2014).

Bağımsız denetim ile ilgili yaşanan gelişmeler doğrultusunda, denetçi özelliklerine yönelik yapılan akademik çalışmalar da artış göstermeye başlamıştır. Literatüre bakıldığında denetim kalitesine etki edebilecek denetçi özelliklerinden olan cinsiyetten kaynaklı olarak farklılıklar 
ortaya çıkmaktadır. Erkek denetçinin bilgi edinme stratejisi biraz daha basit ve sezgisel olurken; kadın denetçinin bilgi edinme stratejisi daha ayrıntılı olmaktadır. Bu da kadın denetçilerin finansal tablolardaki hata ve hileleri erkeklere oranla daha çok tespit edebilmelerini sağlamaktadır (Meyers ve Levy, 1989).

Bengtsson, Persson ve Willinhag (2005) çalışmalarında, denetim sürecinde zaman baskısının kadınları erkeklere göre daha çok etkilediğini vurgulamışlardır. Kadın denetçilerin erkek denetçilere göre finansal tablolara ilişkin hata ve hile kaynaklı önemli yanlışlıkları rapor etme sıklığı daha fazladır. Fakat bazı durumlarda kadın denetçilerin kendilerine olan güvenin daha az olmasından kaynaklı erkek denetçilere göre finansal tablolardaki hata ve hile kaynaklı yanlışlıkları rapor etme durumu daha az olabilmektedir.

Breesch ve Branson (2009), "Denetçi Cinsiyetinin Denetim Kalitesi Üzerine Etkileri” adlı çalışmalarında, denetçi cinsiyetinin denetim raporu kalitesi üzerindeki etkilerini incelemişlerdir. 20 kadın ve 20 erkek denetçinin örneklem olarak belirlendiği çalışmada yer alan bulgular; kadın denetçilerin, erkek denetçilerden daha fazla yanlışlık keşfetme potansiyeline sahip olduklarını göstermektedir. Çalışmada ayrıca, denetim metodolojisi olarak kadın denetçilerin erkek denetçilere nazaran risk odaklı denetim yaklaşımını daha çok benimsedikleri de ifade edilmektedir.

Thiruvadi ve Huang (2011), denetim komitelerinin cinsiyet çeşitliliğinin firmanın kazanç yönetimi üzerinde önemli bir etkisi olup olmadığını araştırmayı amaçladıkları "Denetim Komitesi Cinsiyet Farklılıkları ve Kazanç Yönetimi" adlı çalışmalarında, denetim komitesinde bir kadın üyenin bulunmasının, negatif (gelir azaltıcı) ihtiyari tahakkukları artırarak kazanç yönetimini sınırladığını gösteren sonuçlar ortaya koymuşlardır.

Denetçi cinsiyetini konu edinen bir diğer çalışmada ise Ittonen ve Peni (2012) "Denetçinin Cinsiyeti ve Denetim Ücretleri" adlı çalışmalarında, denetçinin cinsiyetinin denetim ücretleri üzerindeki etkisini incelemişlerdir. Çalışmada üç İskandinav ülkesinde (Finlandiya, İsveç ve Danimarka) NASDAQ OMX borsalarında yer alan bir halka açı şirket örneklemi kullanılarak gerçekleştirilen araştırma sonucu, kadın denetim sözleşmesi ortaklarına sahip işletmelerin önemli ölçüde daha yüksek denetim ücretleri ödediklerini göstermiştir.

"Muhasebe Meslek Mensubunun İşyeri Deneyimi ve Toplumsal Cinsiyet Etik Yargılamayı Nasıl Etkiler?" adlı çalışmalarında Lv ve Huang (2012), bireylerin etik davranışlarının ve ahlaki yargılarının, çalıştıkları veya uyguladıkları disiplinden ve cinsiyetlerinden nasıl etkilendiğini araştırmıştır. Araştırma sonuçları, erkeklerle karşılaştıııldığında kadınların şüpheli eylemleri daha az etik gördüklerini ve bu eylemleri gerçekleştirme olasılıklarının daha düşük olduğunu göstermiştir. Çalışmada ayrıca denetçinin cinsiyeti ile müşteri işletmenin finansal raporlarının kalitesi arasındaki ilişki de araştııılmıştır. Bu doğrultuda çalışmada, sorumlu denetçisi kadın olan işletmelerin finansal raporlarının daha kaliteli olduğu sonucuna ulaşılmıştır.

Cinsiyet ve denetim komitesi ilişkisini ele alan Thiruvadi (2012) tarafından gerçekleştirilen "Cinsiyet Farklılıkları ve Denetim Komitesi Titizliği" başlıklı çalışmada, denetim komitesinde kadınların varlığı ile denetim komitesi toplantılarının sayısı arasındaki ilişkinin incelenmesi amaçlanmıştır. Bu amaçla çalışmada çok değişkenli regresyon modeli kullanılmıştır. Araştırma sonuçlarına göre en az bir kadın üyenin bulunduğu denetim komitelerinin, erkek yoğun denetim komitelerinden daha sık toplandığını göstermektedir.

Denetçi cinsiyeti ile denetim ve finansal raporlama kalitesini konu edinen bir başka çalışma ise Ittonen, Vahamaa ve Vahamaa (2013) tarafından gerçekleştirilmiştir. "Kadın Denetçiler ve Kalite Artışları" adlı çalışmada Finlandiya ve İsveç Borsalarındaki işletmelerden bir örnek belirlenerek, kadın denetçi ve finansal raporlama kalitesi değişkenlerini kullanarak panel Regresyon Analizi 
gerçekleştirilmiştir. Çalışmada kadınlar ve erkekler arasındaki davranışsal farklılıkların denetim ve finansal raporlama kalitesi üzerinde önemli etkileri olabileceği yönündeki bulguya ulaşılmıştır.

Hardies, Breesch, ve Branson (2015) tarafından gerçekleştirilen “Kadın Denetçi Ücret Primi” adlı çalışmalarında; kadın denetçilere daha yüksek denetim ücreti ödenip ödenmediğini araştırmışlardır. 2008-2011 yılları arasında 93 kadın ve 599 erkek denetim ortağı tarafından denetlenen Belçikalı işletmeler analiz edilmiştir. Analiz sonuçlarına göre müşteri işletmelerin kadın denetçilere daha yüksek denetim ücretleri (yaklaşık yüzde 7 oranında) ödediğini göstermektedir. Çalışmada ayrıca söz konusu daha yüksek denetim ücretlerinin; bilgi, beceri, yetenekler, tercihler ve davranışlardaki cinsiyet farklılıkları veya arz yönlü faktörler (örneğin, çeşitlilik talebi, denetim kalitesi ile ilgili cinsiyet algıları veya müşteri memnuniyeti) nedeniyle olabileceği de ifade edilmiştir.

Montenegro ve Bras (2015) “Denetim Kalitesi: Denetim Firmalarının Cinsiyet Yapısı Önemli midir?" başlıklı çalışmalarında; Portekiz'deki denetim firmalarından ve müşteri işletmelerden oluşan bir örneklem kullanarak, denetim firmalarının ortaklık yapısı (cinsiyet açısından) ile denetim kalitesi arasındaki ilişkiyi incelemektedirler. Denetim firmalarındaki ortak pozisyonundaki kadın Yeminli Mali Müşavirlerin baskın mevcudiyetinin daha yüksek denetim kalitesiyle ilişkili olduğu çalışma bulguları arasında yer almaktadır. Ayrıca çalışmada, kadın egemen ortaklık yapılarına sahip denetim firmalarının müşteri işletmelerindeki agresif muhasebe uygulamalarının daha az olduğu sonucuna ulaşılmıştır.

Reheul ve diğerleri (2017), "Kâr Amacı Gütmeyen Kuruluşlarda Denetçi Cinsiyeti, Deneyimi ve Raporlaması" adlı çalışmalarında Belçikalı kar amacı gütmeyen kuruluşlarda bağımsız denetçi özellikleri ile denetim görüşleri arasındaki ilişkiyi araştırmayı amaçlayarak, finansal tablo kalitesine daha iyi bir güvence veren denetçi özelliklerini tanımlamaya çalışmışlardır. Çalışmanın sonuçlarına göre sektör uzmanlığına sahip denetçilerin, sektör uzmanı olmayan meslektaşlarına göre daha iyi güvence sağladığı bulunmuştur. Ayrıca denetçinin kadın veya erkek olmasının denetim görüşü üzerinde farklılığa sebep olmadığı tespit edilmiştir.

Blandona, Argiles-Bosch ve Ravenda (2019), “Denetim Hizmetlerinin Kalitesi Üzerinde Cinsiyet Etkisi Var Mıdır?" başlıklı çalışmalarında, İspanyol borsa şirketlerinin 2008-2015 yıllarına ait finansal tablo verileri kullanılmıştır. Denetim hizmetlerinin kalitesi üzerinde, kadın denetçinin pozitif bir etkisinin bulunduğu araştırma sonucunda elde edilen bulgular arasında yer almaktadır. Ayrıca, araştırma sonuçlarına göre kadınların sadece muhasebe mesleğinde ve denetim firmalarında değil, aynı zamanda diğer alanlarda da üst yönetimde yeterince temsil edilmediği de ifade edilmiştir.

Özbey ve Özarı (2020), "Borsa İstanbul İmalat Sanayi İşletmelerinin Kârlılığa Etki Eden Faktörlerinin Panel Regresyon ile İncelenmesi" adlı çalışmalarında Borsa İstanbul' da (BİST) işlem gören imalat sanayi işletmelerinin kârlılık oranlarının bazı finansal oranlarla ve denetimin 4 büyük denetim firması tarafından yapılmış olması, denetçi cinsiyeti ve olumlu görüş gibi finansal olmayan faktörlerle ilişkisi analiz edilmiştir. Analiz yöntemi olarak Panel Veri Regresyon yöntemi kullanılmıştır. Çalışma sonuçlarına göre, işletmelerin kârlılı̆̆ üzerine etki eden finansal oranların; likidite oranları, kaldıraç oranı, maddi duran varlık devir hızı, aktif kârlılı̆̆ı, hisse başına kazanç piyasa değerinin defter değerine oranı olduğu tespit edilmiştir. Finansal olmayan oranlardan denetçi cinsiyeti ve olumlu denetim görüşü faktörlerinin de işletme karlılığını etkilediği sonucuna ulaşılmıştır.

\section{YÖNTEM}


Bu çalışmada bağımsız denetçi cinsiyetinin denetim görüşü üzerindeki etkisi araştırılmıştır. Bu doğrultuda bağımlı değişken olarak denetim görüşü, bağımsız değişken olarak ise denetçi cinsiyeti belirlenmiştir. Çalışmanın örneklemini BIST 100 endeksindeki 100 işletme oluşturmuştur. Verilerin analizi SPSS 20.0 İstatistik Programı ile gerçekleştirilmiştir. Çalışmada kullanılan veriler, KAP'ın web sayfasında yayınlanan işletmelerin faaliyet raporlarından elde edilmiştir.

Bağımsız değişkenin, bağımlı değişken üzerindeki etkisini ölçmek için parametrik test yöntemlerinden Regresyon Analizi kullanılmaktadır. Regresyon Analizi, en çok kullanılan çok yönlü bağımlılık tekniğidir ve karar verme sürecinin her alanında uygulanabilmektedir. Regresyon Analizi, belirli bir sektördeki bir işletmenin performansının modeline ve belli girdi gelirlerine dayalı ulusal ekonomiyi tahmin eden ekonometrik modellere uygulanabilir. Ayrıca Regresyon modelleri, tüketicilerin kararları nasıl aldığını veya izlenimlerini ve tutumlarını nasıl oluşturduklarını incelemek için de kullanılabilmektedir (Hair vd., 2010).

Regresyon Analizinin varsayımları aşağıdaki gibidir (Kalaycı, 2010):

1. Örneklem sayısı $30^{\prime}$ un üzerinde olmalıdır.

2. Normal dağılım göstermelidir.

3. Doğrusaldır.

4. Hata terimlerinin ortalaması sıfırdır.

5. Sabit varyansdır.

6. Otokorelasyon yoktur.

7. Bağımsız değişkenler arasında çoklu bağıntı sorunu olmamalıdır.

Çalışmada örneklem sayısı 30'un üzerindedir. Regresyon Analizinin ikinci şartı olan verilerin normal dağılıp dağılmadığını kontrol etmek için normallik analizi gerçekleştirilmiştir. Normallik analizi sonuçlarına göre verilerin normal dağılmadığı görülmüştür. Bundan dolayı parametrik olmayan testlerin kullanılması gerektiği sonucuna varılmıştır. Parametrik olmayan testler içerisinden, bağımsız değişkenin, bağımlı değişken üzerindeki etkisini ölçmek için Ki-Kare Bağımsızlık Testi kullanılmıştır.

Ki-Kare Bağımsızlık Testi Scheuneman ve Camilli (1979) tarafından geliştirilmiştir. Nitel iki değişken arasında istatistiksel olarak anlamlı bir ilişki olup olmadığı Ki-Kare Bağımsızlık testi ile araştırılabilir. Ki-Kare Bağımsızlık testinde kurulan hipotezlerde; Ho ilişkinin olmadığını, bağımsızlığın olduğunu; $\mathrm{H}_{1}$ ise ilişkinin olduğunu, bağımsızlığın olmadığını ifade eder (Güngör ve Bulut, 2008).

Çalışmanın hipotezleri:

Ho: "Bağımsız denetçi cinsiyeti ile bağımsız denetim görüşü arasında anlamlı bir ilişki yoktur."

Hı: "Bağımsız denetçi cinsiyeti ile bağımsız denetim görüşü arasında anlamlı bir ilişki vardır." şeklinde oluşturulmuştur.

Ki-Kare Bağımsızlık test istatistiğinin hesaplanması için aşağıdaki formül kullanılmaktadır (Kalayc1, 2010).

$$
\chi^{2}=\sum_{i=1}^{m} \sum_{j=1}^{n} \frac{(O i j-E i j)^{2}}{E i j}
$$

Eij = Değişkenlere ait beklenen frekanslar ( $\mathrm{H}_{0}{ }^{\prime}$ da iddia edilen dağılıma ait değerlerdir.)

$\mathrm{Oij}=$ Değişkenlere ait gözlenen frekanslar ( $\mathrm{H}_{1}$ 'de iddia edilen dağılıma ait değerlerdir.) 
Analiz verilerine Ki-Kare Bağımsızlık testi uygulanmış ve elde edilen sonuçlar bir sonraki bölüm olan bulgular kısmında değerlendirilmiştir.

\section{BULGULAR}

Verilerin Regresyon Analizinin koşullarını sağlayıp sağlamadığını belirlemek için analize Normallik testinin yapılmasıyla başlanmıştır. Normallik testinin sonuçlarına göre verilerin normal dağılım göstermediği görülmüştür.

Tablo 1.Normallik Testi (Tek Örneklem Kolmogorov-Smirnov Testi)

\begin{tabular}{|l|l|r|r|}
\hline \multicolumn{2}{|c|}{} & \multicolumn{1}{|c|}{ Denetçi Görüşü } & Denetçi Cinsiyeti \\
\hline Örneklem Sayıs1 & 100 & 100 \\
\hline \multirow{2}{*}{ Normal Parametreler } & Ortalama & 1,08 & 1,81 \\
\cline { 2 - 4 } & Standart Sapma &, 273 &, 394 \\
\hline \multirow{3}{*}{ Aşırı Farklar } & Mutlak &, 535 &, 495 \\
\cline { 2 - 4 } & Pozitif &, 535 &, 315 \\
\cline { 2 - 5 } & Negatif &,- 385 &,- 495 \\
\hline Kolmogorov-Smirnov Z & 5,354 & 4,951 \\
\hline Anlamlılık (2-tailed) &, 000 &, 000 \\
\hline
\end{tabular}

Tablonun anlamlılık satırındaki değerlerin istatistiksel anlamlılık hesaplamalarında sınır değeri kabul edilen $0,05^{\prime}$ den büyük olması incelenen faktörlerin dağılımlarının normal olduğunu göstermektedir. Tablo 1'de görüldüğü üzere anlamlılık değeri 0,05'ten küçük olduğu için veriler normal dağılmamaktadır $(\mathrm{p}=0,000<0,05)$. Bundan dolayı parametrik olmayan test yöntemlerinin kullanılması gerekmektedir.

Veriler normal dağılım göstermediği için parametrik olmayan bir analiz yönteminin kullanılmasına karar verilmiştir. Bu doğrultuda bağımsız değişkenin bağımlı değişken üzerindeki etkisini ölçmek için Ki-Kare Bağımsızlık Testi kullanılmıştır. Analiz sonuçları Tablo 2 'de ve Tablo 3 'te sunulmuştur.

Tablo 2. Denetçi Cinsiyeti * Denetçi Görüşü Çapraz Tablolama

\begin{tabular}{|c|c|c|c|c|c|}
\hline & \multicolumn{2}{|c|}{ Denetçi Görüşü } & \multirow[t]{2}{*}{ Toplam } \\
\hline & & & Olumlu & Şartlı & \\
\hline \multirow{8}{*}{ Denetçi Cinsiyeti } & \multirow{4}{*}{ Kadın } & Say1 & 17 & 2 & 19 \\
\hline & & Tahmini Sayı & 17,5 & 1,5 & 19,0 \\
\hline & & Denetçi Cinsiyeti İçindeki \% & $89,5 \%$ & $10,5 \%$ & $100,0 \%$ \\
\hline & & Denetçi Görüşü İçindeki \% & $18,5 \%$ & $25,0 \%$ & $19,0 \%$ \\
\hline & \multirow{4}{*}{ Erkek } & Say1 & 75 & 6 & 81 \\
\hline & & Tahmini Say 1 & 74,5 & 6,5 & 81,0 \\
\hline & & Denetçi Cinsiyeti İçindeki \% & $92,6 \%$ & $7,4 \%$ & $100,0 \%$ \\
\hline & & Denetçi Görüşü İçindeki \% & $81,5 \%$ & $75,0 \%$ & $81,0 \%$ \\
\hline \multirow{4}{*}{\multicolumn{2}{|c|}{ Toplam }} & Say1 & 92 & 8 & 100 \\
\hline & & Tahmini Say1 & 92,0 & 8,0 & 100,0 \\
\hline & & Denetçi Cinsiyeti İçindeki \% & $92,0 \%$ & $8,0 \%$ & $100,0 \%$ \\
\hline & & Denetçi Görüşü İçindeki \% & $100,0 \%$ & $100,0 \%$ & $100,0 \%$ \\
\hline
\end{tabular}

Tablo 2'den elde edilen sonuçlara göre; 100 işletmeye ait denetim görüşleri denetçi cinsiyetine göre şu şekilde dağılmaktadır: Toplam 19 kadın denetçiden 17'si "olumlu görüş" bildirirken, 2'si "şartlı görüş" bildirmiştir. Toplam 81 erkek denetçiden ise 75'i olumlu görüş bildirirken, 6 's ş̧artlı görüş bildirmiştir. "Olumsuz görüş" ve "görüş bildirmekten kaçınma" görüş türleri bulunmamaktadır. 
Tablo 3. Ki-Kare Testi

\begin{tabular}{|l|l|l|l|}
\hline & Value & df & Anlamlllı (2-sided) \\
\hline Pearson Ki-Kare &, 203 & 1 &, 652 \\
\hline Süreklilik Düzeltmesi &, 000 & 1 & 1,000 \\
\hline Olabilirlik Oranı &, 191 & 1 &, 662 \\
\hline Doğrusal İlişkilendirme &, 201 & 1 &, 654 \\
\hline N Örnek Sayısı & 100 & & \\
\hline
\end{tabular}

Analiz sonuçlarına göre anlamlılık düzeyi 0,05 ' den büyük olduğu için sonuçlar anlamlı değildir $(p=0,652>0,05)$. Buna göre "Bağımsız denetçi cinsiyeti ile bağımsız denetim görüşü arasında anlamlı bir ilişki vardır" H1 Hipotezi reddedilmiştir. Yani "Bağımsız denetçi cinsiyeti ile bağımsız denetim görüşü arasında anlamlı bir ilişki yoktur." H0 hipotezi kabul edilmiştir.

\section{TARTIŞMA, SONUÇ VE ÖNERILER}

Günümüzde küresel ekonomi giderek gelişip ilerlemektedir. Bu gelişme ve ilerlemeyle birlikte işletmelerin faaliyetleriyle ilgilenen çıkar grupları sayısı da artmaktadır. Bu doğrultuda işletmeler tarafından sunulan bilgilerin doğruluğu sorgulanmakta ve dolayısıyla ortaya güvenilir bilgi ihtiyacı çıkmaktadır. Güvenilir bilginin sunulmasında bağımsız denetim faaliyetleri ve bağımsız denetçiler büyük önem taşımaktadırlar.

Bağımsız denetim alanında Kalite Kontrol Standartları, yasal düzenlemeler, yıllık gözden geçirmeler ve kamuya açıklanması zorunlu raporlar olmasına rağmen, bağımsız denetim raporunu hazırlayan sorumlu denetçi kendi mesleki bilgisini ve tecrübesini kullanarak bir denetim görüşü oluşturur (Knechel, Niemi ve Zerni, 2013). Bağımsız denetim ile ilgili yaşanan gelişmeler sonucunda denetçilerin sahip olduğu özellikler (cinsiyet, sektör uzmanlığı vb.) denetim sürecini, denetim ücretlerini etkileyebilmektedir. Bu doğrultuda denetçilerin sahip olduğu kişisel ve mesleki özelliklerden yola çıkılarak çok sayıda akademik çalışma yapılmıştır.

$\mathrm{Bu}$ çalışmada ise denetçinin kişisel özelliklerinden birisi olan cinsiyetin, denetim faaliyeti sonucunda oluşturulan ve denetim raporunda bildirilen denetim görüşüne etkisi olup olmadığının araştırılması amaçlanmıştır. Bu amaçla gerçekleştirilen istatistiksel analizler sonucunda; bağımsız denetim faaliyetini gerçekleştiren denetçinin cinsiyetinin, denetim faaliyeti sonucunda varılan denetim görüşü üzerinde etkisi olmadığı ortaya çıkmıştır.

Genel Etik İlkelere bakıldığında (Bağımsız Denetçiler İçin Etik Kurallar Standardı, Bölüm 110, 2019) bağımsız denetim raporundaki denetçi imzasının bir kadın ya da erkek denetçiye ait olmasının herhangi bir fark yaratmasının beklenmemesi gerektiği ifade edilmektedir. Çünkü bir meslek mensubu eğer etik ilkelerin temelini oluşturan dürüstlük, tarafsızlık, mesleki yeterlilik ve özen, gizlilik ve profesyonel davranış kriterlerini taşıyorsa cinsiyetinin kadın ya da erkek olması önemli olmamalıdır (Bozcuk, 2018). Bu anlamda analiz sonuçlarına bakıldığında olması gereken sonuçların ortaya çıktığı görülmektedir.

Literatür incelendiğinde bağımsız denetçi özellikleri ile ilgili çok sayıda çalışma yapılmış olmasına rağmen, bağımsız denetçi cinsiyetinin, denetim görüşü üzerine etkisi konusunda yapılmış çalışma sayısı azdır. Bundan dolayı bu çalışmanın literatüre katkı sağlaması beklenmektedir.

İş dünyasında kadın çalışanların erkek çalışanlara oranla daha az sayıda yer almasından kaynaklı olarak, bu çalışmanın örnekleminde yer alan kadın denetçi sayısının düşük olması bu çalışmanın kısıtıdır. Gelecekte bu konu ile ilgili yapılan çalışmalarda; yıl ve sektör sayısı artırılarak örneklem 
büyüklügü genişletebilir. Farklı ülkelerden elde edilen veriler çalışmaya dâhil edilerek ülkeler arası karşılaştırmalar yapılabilir. Ayrıca gelecekte denetim sürecinin bileşenleri (risk değerleme, örnekleme, önemlilik, denetim testleri, denetim teknikleri vb.), mesleki şüphecilik, mesleki muhakeme üzerinde cinsiyet farklılığının etkisi de araştırılabilir.

\section{KAYNAKÇA}

Bağımsız Denetçiler İçin Etik Kurallar Standardı (2019, 22 Eylül). Resmi Gazete (Sayı: 30896), https://www.resmigazete.gov.tr/eskiler/2019/09/20190922.htm, (Erişim Tarihi: 06.06.2020)

Bağımsız Denetim Yönetmeliği (2015, 22 Aralık). Resmi Gazete (Sayı: 28509). Erişim Adresi: https://www.resmigazete.gov.tr/eskiler/2015/12/20151222.htm, (Erişim Tarihi: 12.05.2020)

Bağımsız Denetim Yönetmeliği, 22. 12. 2015 Tarih ve 28509 Sayılı Resmi Gazete.

Bengtsson, C., Mats, P. and Peter, W. (2005). Gender and Over Confidence. Economics Letters, (86), 199-203.

Blandona, J. G., Argilés-Boschb, J. M. and Ravenda, D. (2019). Is There A Gender Effect On The Quality Of Audit Services?. Journal of Business Research, 96 (1), 238-249.

Bozcuk, A. E. (2018). Türkiye'deki Bağımsız Denetim Kuruluşlarında Üst Düzeydeki Cinsiyet Çeşitliliği ve Gelir Etkisi. Uluslararası Sosyal Araştırmalar Dergisi, 11 (59), 882-890.

Breesch, D. and Branson, J. (2009). The Effects Of Auditor Gender On Audit Quality. IUP Journal of Accounting Research \& Audit Practices, 8.

Erdoğan, M. (2002). Muhasebe, Denetim ve Bağımsız Denetimin Gerekliliği. Doğuş Üniversitesi Dergisi, 3 (1), 51-63.

Finansal Tablolara İlişkin Görüş Oluşturma ve Raporlama (BDS 700) Hakkında Tebliğ Türkiye Denetim Standartları Tebliği No: 30, 18.03.2014 Tarih ve 28945 Sayılı Resmi Gazete, https://www.resmigazete.gov.tr/eskiler/2014/03/20140318.htm, (Erişim Tarihi: 10.06.2020)

Güngör, M. ve Bulut, Y. (2008). Ki-Kare Testi Üzerine. Doğu Anadolu Bölgesi Araştırmalarl, 84-89.

Hair, J. F., Anderson, R. E., Babin, B. J., and Black, W. C. (2010). Multivariate Data Analysis: A Global Perspective, (7).

Hardies, K., Breesch, D. And Branson, J. (2015). The Female Audit Fee Premium. Auditing: A Journal of Practice \& Theory, 34 (4), 171-195.

Ittonen, K. ve Peni, E. (2012). Auditor's Gender and Audit Fees. International Journal of Auditing, (16), 1-18.

Ittonen, K., Vahamaa, E. and Vahamaa, S. (2013). Female Auditors and Accruals Quality. Accounting Horizons, 27 (2), 205-228.

Kalaycı, Ş. (2010). SPSS Uygulamalı Çok Değişkenli İstatistik Teknikleri. Ankara: Asil Yayın Dağıtım.

Knechel, W. R., Niemi, L. and Zerni, M. (2013). Empirical Evidence on the Implicit Determinants of Compensation in Big 4 Audit Partnerships. Journal of Accounting Research, 51 (2), 349387.

Lagerberg F. and Schmidt, K. (2020). Women in Business 2020: Putting the Blueprint into Action. https:/www.grantthornton.global/globalassets/1.-member-firms/global/insights/womenin-business/2020/women-in-business-2020_report.pdf, (Erişim Tarihi: 25.06.2020) 
Lv, W. and Huang, Y. (2012). How Workplace Accounting Experience and Gender Affect Ethical Judgment. Social Behavior and Personality an International Journal, 40 (9), 1477-1483.

Meyers Levy, J. (1989). Gender Differences in Information Processing: A Selectivity Interpretation. New York: Lexington Boks.

Montenegro, T. M., and Bras, F. A. (2015). Audit Quality: Does Gender Composition of Audit Firms Matter?. Spanish Journal of Finance and Accounting, 44 (3), 264-297.

Özbey, S. ve Özarı, Ç. (2020). Borsa İstanbul İmalat Sanayi İşletmelerinin Kârlılığa Etki Eden Faktörlerinin Panel Regresyon İle İncelenmesi. Business \& Management Studies: An International Journal, 8 (1), 541-574.

Parlaktuna, İ. (2010). Türkiye'de Cinsiyete Dayalı Mesleki Ayrımcılığın Analizi. Ege Akademik Bakış, 10 (4), 1217-1230.

Reheul, A. M., Van Caneghem, T., Van den Bogaerd, M., \& Verbruggen, S. (2017). Auditor Gender, Experience and Reporting in Nonprofit Organizations. Managerial Auditing Journal.

Selimoğlu Kardeş, S. Ve Yeşilçelebi, G. (2014). Mesleki Aidiyetin Bağımsız Denetim Kalitesi Üzerine Etkisi: Bağımsız Denetçiler Üzerine Bir Araştırma. Muhasebe ve Finansman Dergisi, (64), 27-52.

Selimoğlu Kardeş, S., Özbirecikli, M. ve Uzay, Ş. (2017). Bağımsız Denetim (1. Basım). Ankara: Nobel Yayıncilik.

Selimoğlu, S., Cengiz, A. A., Özdemir, A., Yalı, B. ve Yiğit, M. (2020). Sayıların Görül(e)meyen Kahramanları Kadın Muhasebeciler: Eskişehir'de Keşifsel Bir Çalışma. Muhasebe ve Denetime Bakış, 60, 1-18.

Sermaye Piyasasında Bağımsız Denetim Standartları Hakkında Tebliğ, 12.06.2006 Tarih ve 26196 Sayılı Resmi Gazete, https://www.resmigazete.gov.tr/eskiler/2006/06/20060612M1-1.htm, (Erişim Tarihi: 11.05.2020)

Thiruvadi, S. (2012). Gender Differences And Audit Committee Diligence. Gender in Management: An International Journal, 27 (6), 366-379.

Thiruvadi, S. and Huang, H. W. (2011). Audit Committee Gender Differences And Earnings Management. Gender in Management: An International Journal, 26 (7), 483-498. 